\title{
Seasonal Disparity in Microbial and Soil Transmitted Helminths Concentrations in Irrigation Samples
}

\author{
A. Abubakari ${ }^{1,2^{*}}$, E. Degraft-Johnson ${ }^{3}$, J.A. Larbi ${ }^{1}$ and RC. Abaidoo ${ }^{1}$ \\ ${ }^{1}$ Department of Theoretical and Applied Biology, ${ }^{3}$ Department of Mathematics, \\ Kwame Nkrumah University of Science and Technology, Kumasi-Ghana \\ ${ }^{2}$ Department of Laboratory Technology, Faculty of Health Sciences, Kumasi Technical \\ University, Kumasi-Ghana \\ *Corresponding author
}

K e y w o r d s
Wastewater
irrigation,
Microbial, Seasonal
and Soil transmitted
helminths

\section{Keywords}

Wastewater

and Soil transmitted

helminths

\section{A B S T R A C T}

This study was conducted to assess the concentrations of microbial pathogens and Soil Transmitted Helminths (STH's) as an initial step in the health risk reduction and reuse strategies in wastewater irrigation practices. Kumasi where the study was conducted is the second largest city in Ghana having significant number of farmers who engage in unrestricted wastewater irrigation practices. Field and laboratory analysis was carried out within 40 weeks covering both the dry and the wet seasons for almost all the irrigation sites within the city. Samples collected and analyzed included wastewater used for irrigation, Manured soil and Lettuce irrigated with wastewater. Samples analyzed in the laboratory resulted in identification and quantification of microorganisms with $E$. coli and Total coliforms presenting mean levels exceeding WHO recommendations $1 \times 10^{3} / 100 \mathrm{ml}$ and $\leq 1 \mathrm{egg} / \mathrm{L}$ for unrestricted irrigation. This study showed significant difference between the concentrations presented within the dry and wet seasons with the $P$-values far less than 0.05 ( $<0.05$ ). With that notwithstanding, E. coli O157:H7 showed no significant difference between the seasons for manured soil $(P=0.107)$. For the STH's With the exception of $T$. trichiura which had it concentrations in both seasons $\leq 1 \mathrm{egg} / \mathrm{L}$ which conforms to WHO recommendations, A. lumbricoides and A. duodenale were in excess of 1or 2 eggs. This result therefore calls for strict measures and policies for farmers who engage in unrestricted irrigation practices.

\section{Introduction}

Rapid urbanization and population growth has put a lot of pressure on food security and fresh water supply. Due to this challenge, farmers in developing world use polluted water for irrigating their crops. In Ghana studies revealed that most of the surface water used for irrigation are heavily polluted and therefore not appropriate for unrestricted irrigation practices (Mensah et al., 2001). It was also established by Cornish et al., (2001), that in Kumasi alone, about 12,000 farmers are involved in vegetable farming during the dry seasons. Farmers rely on the urban wastewater as inputs for production which 
also allows them to grow multiple cycles in a year. Urban wastewater has rich essential plant nutrients, therefore given farmers the opportunity to gain high yields with only little financial input. However, the uncontrolled reuse of wastewater poses serious threats to public health because of the fecal-oral transmission route. Wastewater contains various pathogens including helminth, bacteria and viruses that were passed by the infected host's excreta (Toze, 2006). These pathogens can survive in water for weeks to month, putting the farmer and all field workers at risk of infection. However, not only farmers and field-workers are at risk, crops grown with wastewater can be contaminated with pathogens, thus also placing the consumers at risk. Farm workers and other population exposed to wastewater irrigation practices have high prevalence of infection with Ascaris, hookworm and other enteric infections (Ensink et al., 2005; Blumenthal and Peasey, 2002). A cross sectional study conducted in Faisalabad in Pakistan, revealed a significant E. coli outbreaks may well have been linked to leafy salad vegetables but were not proven, e.g., an outbreak in 1995 involving leafy lettuce occurred in Montana affecting more than 70 people (Ackers et al., 1998), and another one in Minnesota in 2005 infected 12 people who ate bagged salads (Anonymous, 2005). A study revealed increase in risk of STH infections in wastewater farming households than those that do not engage in wastewater irrigation practices (Ensink et al., 2005).

\section{Objectives of study}

This study sought to; 1) identify the multiple exposure pathways linked to wastewater irrigation practices 2) measure the concentration of pathogens in irrigation water, manured soil and lettuce irrigated with wastewater relation to seasonality.

\section{Materials and Methods}

\section{Study area and design}

This study was carried out in the Kumasi Metropolis from August to June covering both the dry and the wet seasons. The study area was chosen because; it is the second largest city in Ghana with a population size of $2,035,064$ and a household size of 3.8 and an annual growth rate of $2.7 \%$ (Ghana Statistical Service, 2010). Kumasi located in the Ashanti region of Ghana experiences two major seasons, the wet and dry seasons. The wet season starts from March to July which is the major rainy season and minor rains from September to November with an annual rainfall of about $1300 \mathrm{~mm}$. The average minimum and maximum temperatures are $21.5^{\circ}$ and $30.7^{\circ} \mathrm{c}$ respectively. The average humidity is about 84.16 per cent at 0900 GMT and 60 per cent at 1500 GMT. Majority of the people in the region are farmers who unrestricted irrigation all year round. Vegetable Irrigation sites within the City were initially mapped out. There were about 150 farmers with an average of 3 field assistants helping them in their individual farms with others having to be helped by relatives and friends. In all 8 sites were identified and worked with in the study. Each site has approximately 1200 beds with 18-20 farmers. Pretested quality farm-based questionnaires were administered to farmers who participated in the study.

\section{Sampling}

Irrigation water was sampled with 1.5 litter sterile plastic bottles with screwed caps early morning at 0600 hours. Manured soil, Lettuce from irrigation farms were aseptically sampled in triplicate at random into plastic bags (Stomacher ${ }^{(\mathbf{R})}$ ) from lab system from Seward, UK kept in cooling boxes and sent to the laboratory for analysis within the same day. 


\section{Laboratory analysis}

\section{Total coliforms and $E$. coli}

Samples were weighed and homogenized appropriately with distilled water with known volumes. 1millitre of homogenized samples were picked and serially diluted and $10 \mathrm{ml}$ of the diluents added to a beaker containing $90 \mathrm{ml}$ of distilled water mixed with one pack of colisure powder (Quanti-Tray®/2000). The mixture was allowed to stand for some time while shaking it in between to give room for total mixture. It was then poured into the Quant- tray and heat sealed with the Quantitray sealer. Incubation was done at $35^{\circ} \mathrm{c} \pm 0.5$ and the result read after 24 hours using the protocol provided. If sample contained total coliforms then, original yellow wells turned red or magenta. E. coli present in the sample wells metabolized colisure nutrient and fluoresced in a dark room when 6 - watt, $365 \mathrm{~m}$, UV light was passed through the surface of the sample and wells that gave purple colour were counted as E. coli colonies per $100 \mathrm{ml}$ of sample using the most probable number (MPN) table (IDEXX, Westbrook, USA).

\section{Salmonella spp.}

Samples were weighed and blended and then $1 \mathrm{ml}$ which is equivalent to $1 \mathrm{~g}$ of sample were picked with a sterile pipette and added to peptone water incubated at $37^{\circ} \mathrm{c}$ for $18-24 \mathrm{hrs}$. Positive tubes were inoculated into selenite broth, incubated under the same temperature and time. Positive colonies were streaked on Salmonella Shigella (SS) agar plates, and later purified and confirmed with biochemical test and latex agglutination test Oxoid Salmonella Test Kit which is $100 \%$ sensitive and between 97.2\%-100\% specific (Oxoid Limited, 2012)

\section{E.coli 0157:H7}

Samples were mixed with saline, inoculated on Eosine Methylene Blue Agar (EMBA) plates and incubation done at $44^{\circ} \mathrm{c}$ for $24 \mathrm{hrs}$. Plates showing growth of $E$. coli colonies were subculture onto Sorbitol MacConkey ager (SMA) plates and incubated at $44^{\circ} \mathrm{C}$ for 24hrs. Positive colonies were purified (Baron et al; 1994) and serologically confirmed with E. coli prolex $^{\mathrm{TM}}$ latex agglutination test from Oxoid, England which has a specificity and sensitivity $100 \%$ and $99 \%$ respectively (Oxoid Limited, 2012).

\section{Soil transmitted helminth eggs enumeration}

Helminths eggs were enumerated using a combination of the floatation and sedimentation methods (Schwartzbrod, 1998). Samples were diluted up to $2 \mathrm{ml}$ in $4 \mathrm{~L}$ container and allowed to stand overnight to enable the eggs to fully sediment. Series of sedimentation and floatation was carried out according to the protocol. With the aid of a micropipette, as much of the supernatant as possible was sucked up leaving approximately $1 \mathrm{ml}$ of deposit which was picked with a pipette and examined under the microscope. Helminthes eggs were identified using their morphological characteristics compared with the bench aids for the Diagnosis of Intestinal Parasites (WHO, 1994) and expressed as eggs per gram (EPG).

\section{Results and Discussion}

\section{Microbial identification and quantification}

Samples which include, lettuce, wastewater for irrigation and manured soil were assessed quantitatively for E.coli, Total coliforms, salmonella, E.coli 0157:H7 and helminthes eggs. The results obtained were normalized by $\log$ transformation of the coliform unit before an independent $t$ test was applied to find the significance of differences due to seasonality concentrations. Wet and Dry seasons data were compared and analyzed for the concentration level using the log average 
of the log transformation figures. Most data (E.coli and total coliforms) samples recorded in all seasons showed mean levels exceeding $1 \times 10^{3} / 100 \mathrm{ml}$ recommended by WHO (2006) for unrestricted irrigation, moreover, the presence of helminthes egg were evident in all the different samples for the study, and also exceeded the $\leq 1$ egg recommendation by the WHO (2006).

\section{Bacterial concentrations}

Bacterial concentrations were higher in all thedifferent medium (Table 1 and 3), they exceeded WHO level in excess of $3 / 4 \operatorname{logs} / \mathrm{cfu}$ of the concentration levels in all seasons. On the seasonality effects on the concentration level, the dry seasons were lower compared to the levels of concentration in the wet season. However, concentration levels of E.coli 0157:H7 and Salmonella (Table 2 and 4) were lower and meets the WHO level of between 3 to 4 logs/cfu, E. coli 0157:H7 and Salmonella were found to have lower concentration levels. Nevertheless, the concentration levels of bacteria on lettuce, manure soil and wastewater in the seasons showed a significant difference $(p<0.05)$ among them with the exception of E.coli 0157:H7 in manure soil (Table 2). E.coli 0157:H7 also recorded significant different levels of concentration for lettuce and wastewater only (Table 2). Salmonella (Table 4) showed a significant difference in all the different samples indicating different concentration levels due to seasons.

\section{Helminthes egg}

Helminthes eggs presented with high concentration levels in lettuce, manure soil and wastewater in both seasons, the arithmetic mean concentration levels were high for Ascaris spp, and Ancylostoma spp. Trichuris spp had <1egg in all seasons (Table 4) which meets acceptable levels of $\leq 1$ egg.

Table.1 Concentration of total coliform, E. coli, Salmonella spp and E. coli O157:H7 in irrigation water during the wet and the dry seasons

\begin{tabular}{|c|c|c|c|}
\hline $\begin{array}{l}\text { Microorganisms/ } \\
\text { seasons }\end{array}$ & $\begin{array}{l}\text { Mean microbial log } \\
\text { concentrations in } \\
\mathrm{cfu} / \mathrm{ml} \pm \mathrm{SD}\end{array}$ & t-statistic & P-value \\
\hline $\begin{array}{l}\text { Total coliform } \\
\text { Dry season }\end{array}$ & $7.557 \pm 0.201$ & 8.36 & 0.000 \\
\hline Wet Season & $7.915 \pm 0.371$ & & \\
\hline \multicolumn{4}{|l|}{ E. coli } \\
\hline Dry season & $6.619 \pm 0.260$ & 19.04 & 0.000 \\
\hline Wet Season & $7.488 \pm 0.356$ & & \\
\hline $\begin{array}{l}\text { Salmonella spp } \\
\text { Dry season } \\
\text { Wet season } \\
\text { E. coli } O 157: H 7 \\
\text { Dry season }\end{array}$ & $\begin{array}{l}2.524 \pm 0.984 \\
3.692 \pm 0.388 \\
1.100 \pm 1.060\end{array}$ & $\begin{array}{l}2.93 \\
5.57\end{array}$ & $\begin{array}{l}0.017 \\
0.001\end{array}$ \\
\hline Wet Season & $3.282 \pm 0.333$ & & \\
\hline
\end{tabular}

$\mathrm{SD}$ - Standard deviation 
Table.2 Concentration of total coliform, E. coli, Salmonella spp and E. coli 0157:H7 in manured soil during the wet and the dry seasons

\begin{tabular}{|l|l|l|l|}
\hline $\begin{array}{l}\text { Microorganisms/ } \\
\text { seasons }\end{array}$ & $\begin{array}{l}\text { Mean microbial log } \\
\text { concentrations in } \\
\text { cfu/mg } \mathbf{\text { SD }}\end{array}$ & t-statistic & P-value \\
\hline $\begin{array}{l}\text { Total coliform } \\
\text { Dry season }\end{array}$ & $7.684 \pm 0.212$ & 12.62 & 0.000 \\
\hline Wet Season & $7.847 \pm 0.281$ & & \\
\hline E. coli & $6.653 \pm 0.274$ & 18.96 & 0.000 \\
\hline Dry season & $7.417 \pm 0.257$ & & \\
\hline Wet Season & $1.190 \pm 1.02$ & 0.000 \\
\hline $\begin{array}{l}\text { Salmonella } \text { spp } \\
\text { Dry season } \\
\text { Wet season } \\
\text { E. coli } \text { O157:H7 } \\
\text { Dry season }\end{array}$ & $3.694 \pm 0.246$ & 7.53 & 0.107 \\
\hline Wet Season & $1.330 \pm 1.360$ & 2.81 & \\
\hline
\end{tabular}

SD - Standard deviation

Table.3 Concentrations of total coliform, E. coli, E. coli O157:H7 and Salmonella spp in lettuce during the wet and dry seasons

\begin{tabular}{|c|c|c|c|}
\hline $\begin{array}{l}\text { Microorganisms/ } \\
\text { seasons }\end{array}$ & $\begin{array}{l}\text { Mean log microbial } \\
\text { concentration in } \\
\text { cfu/ml } \pm \text { SD }\end{array}$ & t-statisti & P-value \\
\hline $\begin{array}{l}\text { Total coliform } \\
\text { Dry season } \\
\text { Wet season }\end{array}$ & $\begin{array}{l}7.382 \pm 0.170 \\
7.842 \pm 0.307\end{array}$ & 12.62 & 0.000 \\
\hline $\begin{array}{l}\text { E. coli } \\
\text { Dry season }\end{array}$ & $6.456 \pm 0.283$ & 21.15 & 0.000 \\
\hline $\begin{array}{l}\text { E. coli } 0157: H 7 \\
\text { Dry season }\end{array}$ & $0.845 \pm 0.775$ & 8.72 & 0.000 \\
\hline Wet Season & $3.538 \pm 0.259$ & \multirow[b]{2}{*}{10.56} & \multirow[b]{2}{*}{0.000} \\
\hline $\begin{array}{l}\text { Salmonella spp } \\
\text { Dry season } \\
\text { Wet season }\end{array}$ & $\begin{array}{l}0.796 \pm 0.591 \\
3.644 \pm 0.296\end{array}$ & & \\
\hline
\end{tabular}

SD - Standard deviation 
Table 4 Mean egg concentrations and standard deviation of STH's in wastewater, manured soil and lettuce

\begin{tabular}{|c|c|c|c|}
\hline \multirow[t]{2}{*}{ Samples/season } & \multicolumn{3}{|c|}{ Mean egg cocentrations \pm standard error } \\
\hline & Ascaris lumbricoides & $\begin{array}{c}\text { Ancylostoma } \\
\text { duodenale }\end{array}$ & $\begin{array}{l}\text { Trichuris } \\
\text { trichiura }\end{array}$ \\
\hline $\begin{array}{l}\text { Wastewater } \\
\text { Wet season } \\
\text { Dry season }\end{array}$ & $\begin{array}{l}2.11 \pm 0.14 \\
1.58 \pm 0.18\end{array}$ & $\begin{array}{l}0.44 \pm 0.07 \\
1.14 \pm 0.13\end{array}$ & $\begin{array}{l}0.03 \pm 0.02 \\
0.15 \pm 0.06\end{array}$ \\
\hline $\begin{array}{l}\text { Manure Soil } \\
\text { Wet season } \\
\text { Dry season } \\
\text { Lettuce }\end{array}$ & $\begin{array}{l}2.82 \pm 0.23 \\
2.70 \pm 0.19\end{array}$ & $\begin{array}{l}1.26 \pm 0.13 \\
2.06 \pm 0.17\end{array}$ & $\begin{array}{c}0.36 \pm 0.07 \\
0.40 \pm 0.08\end{array}$ \\
\hline $\begin{array}{l}\text { Wet season } \\
\text { Dry season }\end{array}$ & $\begin{array}{l}2.36 \pm 0.25 \\
1.52 \pm 0.13\end{array}$ & $\begin{array}{l}0.87 \pm 0.16 \\
0.99 \pm 0.11\end{array}$ & $\begin{array}{l}0.14 \pm 0.05 \\
0.15 \pm 0.04\end{array}$ \\
\hline
\end{tabular}

Agricultural practices using wastewater need thorough planning supported with careful hygiene protocols. If this is adhered to, most health risk problems associated with this practice could be minimized. More especially among poor countries with pronounce lack of portable water for irrigation and minimal policies on the use of wastewater. The World Health Organization (WHO, 1989) made recommendations for standard thresholds of $10^{3} \mathrm{FC} / 100 \mathrm{ml}$ and $\leq 1 \mathrm{egg} / \mathrm{L}$ of faecal coliform and helminth eggs, respectively in wastewater used for unrestricted irrigation. Manured soil applied by agricultural farmers provides nutrients to the vegetables but introduces a lot of pathogens which poses threats to human health which needs attention (Yang et al., 2004). A study by Rosewell (2010) reported a high prevalence of STH's within urban and peri-urban regions compared to rural dwellings which was attributed to using untreated wastewater for irrigation in these sittings.

This study showed E. coli and Total coliforms concentrations in the examined samples to be high for both seasons with mean levels exceeding the $1 \times 10^{3} / 100 \mathrm{ml}$ recommended by WHO (2006) for unrestricted irrigation. There were excesses of 3 to $4 \operatorname{logs}$ in all seasons which could be attributed to the fact that about $90 \%$ of wastewater generated even in the capital cities of Ghana are not treated and eventually mixed up with storm drain which most farmers rely on for unrestricted irrigation (Scott et al., 2004). The results also confirmed studies by Gupta et al., (2007) which reported high levels (concentrations) of E. coli in vegetables irrigated with wastewater. Amoah et al., (2006) also confirmed in their studies that, drains and streams highly contaminated with faecal coliform concentrations above the WHO acceptable level was the primary water source used in irrigation of most vegetables in Accra. On the assessment of seasonal effects, the dry season samples had lower concentrations of E. coli and total coliform concentrations compared to those reported for the wet season which confirms the studies reported by Seidu et al., (2015). Seidu et al., (2015) indicated that, lettuce from wastewater irrigated farms 
had a six time chance of E. coli $0157: H 7$ contamination during the wet season compared to the dry season which is similar to the observation from this current study. However, this study observed low concentrations of E. coli O157:H7 and Salmonella spp for both seasons meeting the WHO limits of between 3 to $4 \operatorname{logs}$ (WHO, 2006). Although they were present in low concentrations, Salmonella spp and E. coli O157:H7 are reported as having low infectivity dose of 10-100 cells (Wall et al., 1994) and calls for the need for caution. In this study, the low concentration level of $E$. coli 0157:H7 also confirms the study of Donkor et al., (2008) who obtained only 1 (0.4\%) E. coli O157:H7 isolate from E.coli isolates in irrigation water, manured soil and livestock feaces in Accra. Often reports indicate that fresh produce is responsible for about $22 \%$ of all food borne disease infections in the United States from 1999-2004 (Anon, 2006). Research reported by Sivapalasingam et al., (2004) indicated a strong link between lettuce and E. coli O157:H7. Their report further indicated that $29 \%$ (5 out of 17) of all lettuce-related outbreaks were linked to $E$. coli $0157: H 7$ and $38 \%$ (five out of 13) of all E. coli O157:H7 outbreaks with fresh produce were associated with lettuce. Their observation defers slightly from results obtained from this study which could be due to the high temperatures $\left(24.7{ }^{\circ} \mathrm{C}-37.2{ }^{\circ} \mathrm{C}\right)$ experienced during the study which could inhibit the growth of these organisms to some extent. The concentration of Salmonella spp was observed to be a little higher compared to E. coli O157:H7 since it was observed that majority of farmers use poultry manure as organic fertilizer on their farms which has been found to contain high concentrations of Salmonella sp. (Orji et al., 2005). Food-borne disease outbreaks have mostly been linked to consuming vegetables unrestrictedly irrigated with wastewater (Gould et al., 2013). The safety of food depends on a series of events beginning at the level of farm production to consumption with each of such events being essential. Estimates of contaminated food illnesses in developing countries presents a major challenge since infections are mostly treated at home and often not documented (GMJ, 2005). Escherichia coli O157: H7 has been identified as a cause of the life threatening haemolytic uremic syndrome (Banatvala et al., 2001). Although E. coli O157:H7 is primarily associated with animals, contamination of fresh produce and outbreaks attributed to E. coli O157:H7 have been a recurring issue (Erickson and Doyle, 2012). Similarly this current study has shown the presence of E. coli O157:H7 in wastewater irrigated lettuce. Salmonella spp has also been significantly present in the same lettuce samples in which $E$. coli O157:H7were detected. Other studies have noted that E. coli O157:H7 and Salmonella spp infect over 1.6 million humans within United States costing the nation some \$15 billion yearly (Scharff, 2010). This study also detected Salmonella spp and E. coli O157:H7 in wastewater used by farmers for irrigation and lettuce salad from street food which agrees with report from studies that indicated that, pathogenic microorganisms are generally transmitted directly via contaminated foods or indirectly via contaminated water and crops (LeJeune and Kersting, 2010; Pachepsky et al., 2011). The role of free-ranging birds and livestock in pathogen recirculation and local transmission has been noted on and around farms (Gaukler et al., 2009; Cernicchiaro et al., 2012). This is in line with this current study that has detected microbial pathogens in high levels in the manured soil of irrigation fields. It was also revealed during one on one interaction with the farmers that their source of manure was from the major poultry farms within the Kumasi Metropolis which were eventually used untreated. This study observed that farmers mostly used manure from livestock on their farms but these serve 
as pathogen reservoir and consequently serves as a channel for the transmission of pathogens which also agrees with a similar report by Oliveira et al., (2012). Faecal matter of grazing livestock was also frequently observed close to the irrigation areas. These eventually are washed into the nearby irrigation water during a rain fall event increasing contamination by pathogens greatly as also reported by Karesh et al., (2012).

Soil transmitted helminth eggs were detected in all the samples analyzed in the study, and the concentration exceeded the $\leq 1 \mathrm{egg} / \mathrm{L}$ recommended by the WHO (2006) for unrestricted irrigation. In both seasons, Ascaris lumbricoides and Ancylostoma duodenale presented high concentration levels on lettuce, in manured soil and wastewater, with equally high mean concentration levels. This probably explains the $52 \%$ prevalent rate of Ascaris infection in Ghana as reported by Hotez et al., (2003). Again, there is a generally acceptable notion from research studies that, farmers irrigating with wastewater have higher rates of helminth infections than farmers using freshwater (Trang et al., 2006) which could be right due to their constant interaction with these organisms. Additionally they are prone to developing skin and nail problems as a result of these infections when using wastewater for irrigation (Hoek et al., 2002; Trang et al., 2007). High concentrations of microorganisms in wastewater are largely dependent on the level of pollution within the study community (Amann et al., 1998). The high concentrations obtained from this study for both microbial cells and helminthes eggs indicated that the wastewater used by famers for urban and peri-urban agriculture irrigation in some communities within Kumasi may be polluted to some extent. The results from this study confirm the study of Mensah et al., (2001) which found that significantly polluted water is used for irrigation in Ghana. Another study in Kumasi by Keraita et al., (2003) has shown that, the microbiological contaminants in irrigation water sources in most cases exceeded the WHO (1989) guidelines significantly. Other reports from previous researchers (Amoah et al., 2005 and ObiriDanso et al., 2005) indicated that urban rivers and streams in Kumasi which are the main sources of irrigation water for vegetable production are extensively polluted with microbial pathogens. Furthermore, according to Drechsel et al., (2000), the streams in Kumasi metropolis are often contaminated with waste from agricultural lands, abattoirs, brewing and wood processing industries. The presence of helminths eggs in the wastewater was expected as previously reported by Toze (2006). Gastrointestinal infection and weakness which were reported by farm workers during our interaction with them could be related to helminths infection and anaemia due to hookworm infection (Ensink et al., 2005). However, farmers who were engaged in the study during interaction did not admit that their irrigation practices posed threat of acquiring helminths infection which could possibly result in diarrhoea disease cases. This notwithstanding, Pullan et al., (2014) revealed that ascariasis is the most common of the STH's and is endemic in Africa, Latin America, and the Far East and an estimated 133 million people suffer from high-intensity ascariasis infections, which often lead to severe consequences, such as cognitive impairment, severe dysentery and anaemia. The perceptions of farmers have been reported in an earlier study by Rutkowski et al., (2007) in which farmers refused to associate their irrigation practices with infection and diseases. This study detected significant levels of Ascaris spp in lettuce sampled for the study. This is in accordance with the report by Oboubie et al., (2006) which indicated high levels Ascaris and feacal coliforms in lettuce normally 
consumed uncooked compared with other equally eaten raw leafy vegetables irrigated with wastewater in Accra. One other aspect that needs critical attention is the use of manure on the farm; most of the farmers enrolled in this study apply poultry manure on their farms which are sometimes poorly treated or untreated (Drechsel et al., 2000) but may not be aware of its potential health risk.Organic manures contain valuable quantities of nitrogen, phosphate and potash, which act as sources of plant nutrients and are very essential for vegetable growth but may also contain high levels of microbial concentrations and therefore posse health risk to those who directly or indirectly come into contact with them. Such a high level of concentration and continuous exposure of such wastewater and vegetables irrigated with wastewaters to farmers and consumers respectively could lead to a high risk of infection and increases the burden of diseases. An example has been given in a similar study conducted in Malamulele in South Africa (Gumbo et al., 2010) which revealed large numbers of faecal coliform bacteria and helminth eggs among people exposed to wastewater used for irrigation compared with the control group presenting lower levels of faecal coliform bacteria and helminths. This study therefore presented results indicating that microbial loads and helminth eggs assessed surpassed the Tolerable level (TL) of the WHO guidelines which were established to provide protection to irrigation farmers and consumers of crops grown with wastewater (WHO, 1989).

In conclusion, concentration of pathogens show diversity of the presence of microbes and helminth eggs in all forms of the substrates assessed.

Wet seasons recorded high concentration of pathogens compared to the dry seasons which might be due to the prevailing environmental and climatic conditions pertaining within a particular seasons.

In as much as there were differences in the result for the two seasons, there was a high level of pathogen concentration for all the microorganisms from all the different samples used for the study with the exception of the concentration of E.coli $0157: H 7$ on lettuce during the dry season.

\section{Acknowledgement}

The authors acknowledge the contributions of the Norwegian Research Council, Norway and the Department of Theoretical and Applied Biology, KNUST, Kumasi-Ghana and finally, Laboratory Technology Department, Kumasi Technical University, Kumasi-Ghana.

\section{References}

Amann, R., Lemmer, H. and Wagner, M. (1998). Monitoring the community structure of wastewater treatment plants: a comparison of old and new techniques. FEMS Microbiology Ecology, 25, 205215

Amoah, P., Drechsel, P. and Abaidoo, C. (2005). Irrigated urban vegetables production in Ghana: Sources of pathogen contamination and health risk elimination. Irrigation and Drainage, 54, 49-61

Amoah, P., Drechsel, P., Abaidoo, R. C. and Ntow, W. J. (2006). Pesticide and pathogen contamination of vegetables in Ghana's urban markets. Arch. Environ. Contam. Toxicol. 50, 1-6.

Anon, (2006). Waterborne pathogens kill 1020 million people per year. World water and Environmental Engineering 6, aquaculture. Part II Pathogen survival, IRCWD Report No. 04/85

Anonymous,(2005).Health officials investigate $E$. coli O157:H7 cases related 
to Dole pre-packaged lettuce mixes sold at Rainbow Foods. Minnesota Department of Health, News Release, September 30. http://www.health.state. mn.us/news/pressrel/ecoli093005.html, accessed 06.08.12

Banatvala, N., Griffin, P. M., Greene, K. D., Barrett, T. J., Bibb, W. F., Green, J. H. and Wells, J. G. (2001). The United States national prospective haemolytic uremic syndrome study: Microbiologic, serologic, clinical, and epidemiologic findings. J Infect Dis 183:1063-1070.

Baron J., Peterson R. and Finegold (1994). Baily and Scott Diagnostic Microbiology, $9^{\text {th }}$ Ed, C.V. Mosby Company, UK.

Blumenthal, U. J. and Peasey, A. (2002). 'Critical review of epidemiological evidence of the health effects of wastewater and excreta use in agriculture', unpublished document prepared for World Health Organization, Geneva.

Cernicchiaro, N., Pearl D. L., McEwen S. A., Harpster, L., Homan H. J., Linz, G. M. and LeJeune, J. T. (2012). Association of wild bird density and farm management factors with the prevalence of $E$. coli O157:H7 in dairy herds in Ohio (20072009). Zoon Pub Health 59:320-329.

Cornish, G. and Lawrence, P. (2001). 'Informal irrigation in peri-urban areas: A summary of findings and recommendations', Report OD/TN 144, Nov 2001, HR Wallingford Ltd, Wallingford, UK.

Donkor, E.S., Lanyo, R., Akye, M. L., Kayang, B. B. and Quaye, J. (2008).Monitoring Enterohaemorrhagic E. coli $\mathrm{O} 157: \mathrm{H} 7$ in the vegetable food chain in Ghana. Research Journal of Microbiology, 3 (6):423-428

Drechsel, P., Abaidoo, R. C., Amoah, P. and Cofie, O. O. (2000). Increasing Use Of Poultry Manure In And Around Kumasi, Ghana: Is Farmers' Race Consumers'
Fate? Urban Agriculture Magazine, 2, 2527.

Ensink J. H. J., Van der Hoek W., Mukhtar M., Tahir Z. and Amerasnigbe F. P. (2005).High risk of look worm infection among wastewater farmers in Pakistan. Transactions of the Royal Society of Tropical Medicine and Hygiene, 100, 538-542.

Erickson, M. C and Doyle M. P. (2012). Plant food safety issues: Linking production agriculture with One Health. In: Choffnes ER, Relman DA, Olsen L, Hutton R, Mack A. Improving Food Safety Through a One Health Approach. Washington, DC: Institute of Medicine, National Academies Press, 140-175.

Gaukler, S. M, Linz, G. M., Sherwood, J. S., Dyer, N. W., Bleier, W. J., Wannemuehler, Y. M., Nolan, L. K. and Loque, G. M. (2009). E. coli, Salmonella, and Mycobacterium avium subsp. Paratuberculosis in wild European starlings at a Kansas cattle feedlot. Avian Dis. 53, 544-551

Ghana Medical Journal (2005). Editorial commentary on food safety (39), 2

Ghana Statistical Service (2010). Population and Housing Census, Report of Final Result

Gould, L. H., Walsh, K. A., Vieira, A. R., Herman, K., Williams, I. T., Hall, A. J. and Cole, D (2013). Surveillance for foodborne disease outbreaks United States, 1998-2008. Morb Mortal Wkly Rep. 62, 1-34.

Gumbo, J. R., Malaka M. E., Odiyo O.J. and Nare L. (2010). The health implications of wastewater reuse in vegetable irrigation: a case study from Malamulele, South Africa. International Journal of Environmental Health Research 20 (3): 201-211

Gupta, S. K., Keck, J., Ram, P. K., Crump, J. A., Miller, M. A. and Mintz, E. D. (2007). Analysis of data gaps pertaining 
to enterotoxigenic Escherichia coli infections in low and medium human development index countries, 19842005', Part 3, EpidemiologicalInfections, $1-18$

Hoek van der,W.,Ul Hassan, M., Ensink, J. H. J., Feenstra, S., Raschid-Sally, L., Munir, S. (2002). 'Urban wastewater: A valuable resource for agriculture', International Water Management Institute Research Report, no63, Colombo.

Hotez, P.J., de Silva, N., Brooker, S. and Bethony, J. (2003). Soil Transmitted Helminth Infections: The nature, Causes and Burden of Conditions. Working Paper No. 3, Disease Control Priorities Project. International Center, National Institute of Health Bethesda: Maryland.

IDEXX Laboratories, Inc. (2012). A standard method for rapid diagnosis of Coliforms/E.coli in water and wastewater. Westbrook, Main 04092 USA.

Keraita, B., Drechsel, P. and Amoah, P. (2003). Influence of urban wastewater on stream water quality and agriculture in and around Kumasi, Ghana. Environment and Urbanization 15(2): 171-178.

Kumasi Metropolitan Assembly (KMA) Development Plan, (2006-2009). Report for Ministry of Local Government, Rural and Environment Development plan for KMA, (2010-2013)

LeJeune, J. and Kersting A. (2010). Zoonoses: An occupational hazard for livestock workers and a public health concern for rural communities. J Agric Safe Health, 16, 161-179.

Mensah, P., Armar-Klemesu, M., Hammond, A. S., Haruna, A and Nyarko, R. (2001).Bacterial contamination in lettuce, tomatoes, beef and goat meat from the Accra Metropolis. Ghana Medical Journal, 35 (4): 162-167

Obiri-Danso, K., Weobong, C. A. A., Jones, K., (2005). Aspects of health-related microbiology of the Subin, anurtban river in Kumasi, Ghana. J. Water and Health. 3(1): 69-76

Obuobie, E., Keraita. B., Danso, G., Amoah, P., Cofie, O., Raschid-Sally, L. and Drechsel, P. (2006). Irrigated Urban Vegetable Production in Ghana: Characteristics, Benefits andRisks, IWMI-RUAF-CPWF, IWMI, Accra, Ghana

Oliveira, M., Vinas, I., Usall, J., Anguera, M., Abadias, M. (2012). Presence and survival of E. coli $0157: H 7$ on lettuce leaves and in soil treated with contaminated compost and irrigation water. Int. J. Food Microbiol., 156, 133140.

Orji, U. M., Onuigbo, C. H. and Mbata I. Theodore, (2005).Isolation of Salmonella from poultry droppings and other environmental sources in Awka, Nigeria. International Journal of Infectious Diseases. 9(2): 86-89

Oxoid Limited (2012). Diagnostic Reagents for E.coli 0157: H7 \& Salmonella Latex agglutination Test Kits. Oxoid, Basingstoke, Hampshire, England

Pachepsky, Y. (2011). Shelton, D. R, McLain J. E. T, Patel, J. Mandrell RE. Irrigation waters as a source of pathogenic microorganisms in produce. A review, AdvAgron 113:73-138

Pullan, R. L., Smith, J. L., Rashmi Jasrasaria,R., Brooker, S. J (2014). Global numbers of infection and disease burden of soil transmitted helminth infections in 2010. Journal of Parasites \& Vectors, 7 (37): 1-19

Rosewell, A. (2010). Soil-transmitted helminth infection and urbanization in 880 primary school children in Nicaragua, 2005. Trop Doct, 40 (3):141-3 Rutkowski, T., Raschid-Sally, L. and Buechler, S. (2007). Wastewater irrigation in the developing world- Two case studies from Katmandu Valley in 
Nepal. Agricultural Water Management 88 (1-3):83-91

Scharff, R. L. (2010). Health-related costs from foodborne illness in the United States. Availableat: http://www. publichealth.lacounty.gov/eh/docs/Report Publication/HlthRelated CostsFromFoodborneIllinessUS.pdf, accessed July 21, 2014.

Scott, C. A., Faruqui, N. I. and Raschid-Sally, L. (eds) (2004) Wastewater Use in Irrigated Agriculture: Confronting the Livelihood and Environmental Realities, CABI Publishing, Wallingford, UK, pp113-25

Seidu, R., Abubakari, A., Amoah, I. D., Heistad, A., Stenstrom, T.A.,Larbi, A. J., Abaidoo, R. C. (2015). A probabilistic assessment of the contribution of wastewater-irrigated lettuce to E.coli O157:H7 infection risk and disease burden in Kumasi, Ghana. Journal of Water and Health, 1(13):217-229

Sivapalasingam,S., Friedman, C.R., Cohen, L. and Tauxe, R.V. (2004). Fresh produce: A growing cause of outbreaks of foodborne illness in the United States, 1973 through 1997. J Food Prot. 67, 2342-2353

Toze, S. (2006). Reuse of effluent waterbenefits and risks, Agricultural Water Management, 80: 147-159.

Trang, D.T., Van der Hoek, W., Cam, P.D., Vinh, K.T., Hoa, N.V. and Dalsgaard, A. (2006). Low risk for helminth infection in wastewater-fed rice cultivation in
Vietnam. J. Water Health, 4, 321-331

Trang, D.T., Van Der Hoek, W., Tuan, N.D., Cam, P.D., Viet, V.H., Luu, D.D., Konradsen, F. and Dalsgaard, A., (2007). Skin disease among farmers using wastewater in rice cultivation in Nam Dinh, Vietnam. Trop. Med. Int. Health 12 (2): $51-58$

Wall, P.G., Morgan D., Lamden, K., et al., (1994). A case control study of infection with an epidemic strain of multi resistant Salmonella typhimurium DT104 in England and Wales. Commun Dis Rep CDR Rev 4: R130-135

WHO (1989). Health guidelines for the use of wastewater in agriculture and aquaculture: Report of a WHO Scientific Group. WHO Technical Report Series 778. World Health Organization, Geneva. 74.

WHO (1994). Bench aid for the Diagnosis of Intestinal parasites, WHO, Geneva, ISBN 92 (4): $154476-7$.

WHO (2006).Guidelines for the Safe Use of Wastewater, Excreta and Greywater, Volume 2: Wastewater Use in Agriculture, World Health Organization, Geneva

Yang, Q. W., Shu, W.S., Qiu, J. W., Wang, H. B., and Lan, C. Y. (2004). Lead in paddy soils and rice plants and its potential health risk around Lechang Lead/Zinc Mine, Guangdong, and China. Environment International, 30 (4): 883 889.

\section{How to cite this article:}

Abubakari, A., E. Degraft-Johnson, J.A. Larbi and Abaidoo, R.C. 2018. Seasonal Disparity in Microbial and Soil Transmitted Helminths Concentrations in Irrigation Samples. Int.J.Curr.Microbiol.App.Sci. 7(08): 3562-3573. doi: https://doi.org/10.20546/ijcmas.2018.708.360 